\title{
Technology-Transfer Through International Network Formation: Revisiting the Role of Cultural Variation
}

\author{
Ki Hyun Yoo \\ Center for Military Planning at Korea Institute for Defense Analyses KIDA, Seoul, Korea \\ Young Soo Yang \\ Yonsei University, Seoul, Korea
}

\begin{abstract}
This paper studies the factors affecting the technology-transfer within international research and development (R\&D) networks. Specifically, this study examines the characteristics of ties, actors, and international network configuration to assess firm's accessibility to unique technologies. This study was conducted by research analysis in the aerospace industry. The total sample size used in this study is 125 cases of international R\&D consortiums from January 1980 to December 2000. The result of this study supports the effects of "strength of tie" and "characteristic of actors" on the technology transfer explained by network theory. It also demonstrates that the international network structure that would facilitate the technology transfer is shaped by dual type of tie; the apparent type of tie is general, usual, and functional tie, and the hidden one is the national culture.
\end{abstract}

Keywords: the aerospace industry, international research and development (R\&D) network, strength of ties, national culture, technology transfer

\section{Introduction}

On one hand, the study of international technology transfer process is still in its primary stage (Kotabe, Dunlap-Hinkler, Parente, \& Mishra, 2007). In reviewing the traditional literature on technology transfer (Amesse \& Cohendet, 2001; Daghfous, 2004; Sunaoshi, Kotabe, \& Murray, 2005), the general context of the knowledge-based view or learning theory was identified. In this context, the authors focused more on the technology itself, such as demonstrability (Sunaoshi et al., 2005), rather than the process of actual transfer. In the field of international business, however, the transfer process should be theoretically and empirically discussed as the main character of the technology transfer, because the definition of the technology transfer states interaction between two or more social entities (Albors, Sweeney, \& Hidalgo, 2005). Transfer process is also a problem to be solved with different organizational arrangements (Amesse \& Cohendet, 2001). Therefore, it is necessary to fill the gap of the previous researches by focusing more on the transfer process.

On the other hand, most literatures on international technology transfer are based on high-tech industry, such as software (Patibandla \& Petersen, 2002), semiconductors (Hemmert, 2004), pharmaceuticals industry

Ki Hyun Yoo, Ph.D., research fellow, Center for Military Planning at Korea Institute for Defense Analyses KIDA, Seoul, Korea.

Young Soo Yang, Ph.D., lecturer, Business Research Institute, Younsei University, Seoul, Korea.

Correspondence concerning this article should be addressed to Young Soo Yang, Business Research Institute, Yonsei University, 50, Yonsei-ro, Seodaemun-gu, Seoul, Korea. Tel: +82-10-9935-8309. E-mail: seoukore@ hotmail.com. 
(Kotabe et al., 2007), and etc.. However, existing empirical findings of transferring technology seem to have some limitations for industry-specific reasons. The cases of high-tech industry used by prior researches indirectly relate to the issue of the "transfer", because they do not depend on transferring technology to survive.

Also, they excluded the aspect of the international business. The technology transfer among firms in software, semiconductors, and pharmaceuticals industries in the same country or region only revealed the limited relationship. In order to search determinants of technology transfer in the international context, diverse nationalities are needed, because nationality or national culture is a crucial variable in the field of the international business (Hofstede, 1980). Although national culture has been used in many studies in international business, the empirical finding of influences of cultural distance on network outcomes, such as technology transfer, is still scarce in the studies of network theory. Prior researches suggest that national culture is associated with attitudes which affect activities between firms (Sirmon \& Lane, 2004) and knowledge sharing among alliance partners (Parkhe, 1991). These studies, however, have some limitations in creating broader view, because each case focused on the narrow context with researchers' interests, such as difference of national wealth and quality of technology. Then, it is not clear that such findings would be supported under all conditions, including when networks face cultural varience, especially in the global context.

In this study, international research and development (R\&D) consortiums conceptualized as a global network arrangement and examine firm's accessibility to unique technology by analyzing the characteristics of the industry's overall network arrangement and cultural variation. By understanding the pattern of international R\&D network in the aerospace industry, researchers may be able to understand the international network characteristics of the high-tech industry and the peculiarity of international ties affecting the technology transfer. In addition, this study will look into the aspect of international network structure.

\section{Literature Review and Hypothesis}

\section{Technology Transfer in the International R\&D Network}

From the network theory, actors are embedded within a network of interconnected relationships (Brass, Galaskiewicz, Greve, \& Tsai, 2004). Burt (1992) already applied this approach to an extended domain of social phenomena, including relationship beyond the firm. Therefore, a firm's activity as an actor within organizational network can be understood as a process adjusting dyadic ties among firms. Organizational ties among firms function as channels for technology and resource flows, and a firm may gain access to other firms' unique resource through social ties (Tsai, 2001; Hansen, 1999).

Granovetter's study (1992) on social capital classified social ties into weak and strong ties. According to that, the strength of a tie is a combination of the amount of time spent together and the reciprocal services, and these features also characterize the tie. Several studies have sought to identify the characteristics of social ties that lead to technology transfer, for example, according to Hansen (1999), weak ties contribute to the search for sources of information or transfer of non-codified knowledge, but hinder the process of transferring complex technology. Lin, Ensel, and Vaughn (1981) supported the ceiling effect of social networks, arguing that the advantage of weak ties may be restricted by the network's ability to reach useful resources. Moreover, transferring complex technology requires multiplexity of ties (Hansen, Mors, \& Lovas, 2005), because recipients may not acquire the technology completely, during the first interaction with a partner. As partner firms spend more time together, their social tie is likely to be strengthened by their relationship. However, 
frequent contact among firms could become the source of discord. Because firm's separation from a network happens in relation to an organizational network configuration, firms must maintain good relationship without being satisfied with other firms. If durability of network is damaged, firm's ability to acquire unique technology becomes limited (Powell, 1990). In this regard, firm's activity as an actor within an organizational network is a cumulative process in which strength and durability of ties are secured to guarantee short-term and long-term profit (Johanson \& Mattson, 1987). These ties have a variety of purposes, and depending on its purpose, the degree of strength and importance differs (Granovetter, 1973). In some cases, a new tie is neatly integrated into one's previously formed cliques (Gulati, 1998). In others, the tie is kept completely separated from others or introduced only to a limited number of ties. By controlling who knows whom, the firm is able to manage explicitly the network among firms, creating additional connections. When firm's network like the R\&D consortium is sequentially constructed, individual firms act as a bridge through dyadic ties among the firms (Burt, 1992).

The role of international $R \& D$ consortium is becoming increasingly important in high-tech industries, such as aerospace industry. More and more firms are putting pressure on developing unique technology and managing R\&D consortium (Medcop, 2001). If an efficient network can be defined as a cumulative process of forming a relation among firms (Johanson \& Mattson, 1987), firms can acquire valuable technology or skills through strong dyadic ties without own investment (Orru, 1991). In the analysis of new-product development projects of multidivisional and multinational electronics company, Hansen (1999) found that strong interunit ties provide the highest positive effect on completion time, when the knowledge is highly complex, whereas weak interunit ties have the strongest positive effect on completion time when the knowledge is not complex. Moreover, Weimann's study (1982) proves that information via strong ties, as opposed to weak ties, is likely to transfer at higher speed and is attributed with greater credibility. Thus, strong ties serve as better disseminating channels of high-technology for firms in the international business network.

Hypothesis 1: The strength of dyadic tie within network is positively related to technology transfer through international network structure.

\section{Characteristic of Actors Within Organizational Network}

$\mathrm{R} \& \mathrm{D}$ consortium has been broadly defined as an agreement under which firms jointly acquire unique technology (Link \& Bauer, 1989). Several studies have revealed a positive correlation between R\&D activity and alliance formation intensity, especially in technology intensive industries (Hagedoorn, 1993). A firm may greatly advance its innovative capacity by acquiring the skills through transfer of technology from other firms (Pennings \& Harianto, 1992; Gilbert \& Cordey-Hayes, 1996; Szulanski, 1996). Accordingly, as the role of intenational $R \& D$ network is becoming more important, firms in high-tech industry like the aerospace industry are putting pressure to develop unique technology (Medcop, 2001). However, in this industry, it is not always easy to transfer technology to create new or improved products, because the industry fully depends on high-technology. In addition, it is very difficult for firms to simply apply the new technology to create advanced products (Hagedoorn, 1993), because in order to do so, firms generally need the know how to synthesize the existing resources in a new way (Tsai \& Ghoshal, 1998). Furthermore, in order to achieve new productive possibilities, the newly transferred and existing technology must be combined appropriately (Henderson \& Cockburn, 1994). The recipient firm must distinguish needed technology and reject irrelevant technology for an effective flow of technology to occur (Henderson \& Clark, 1990). Closely related technology 
is likely to be more compatible with the firm's existing system than with an unrelated technology, the former will be incorporated with more efficiency (Sapienza, Parhankangas, \& Autio, 2004). Most technologies that share similar traits with existing technology domains are found to be transfering more effectively.

From a network perspective, because almost all firms are linked to one another via direct or indirect ties (Duysters, De Man, \& Wildeman, 1999), similarity among firms is thought to ease communication, increase the predictability of behaviour, and foster trust and reciprocity (Brass et al., 2004). Interaction is influenced by the degree to which an individual actor is similar to other individuals (Mehra, Kildduff, \& Brass, 1998). Empirical evidence shows that a greater tendency for interaction can influence technology transfer (Carley, 1991; McPherson, Smith-Lovin, \& Cook, 2001; Monge \& Contractor, 2003). When actors of a network frequently interact, increased knowledge sharing is a natural product of the interaction (Makela, Kalla, \& Piekkari, 2007). In the organizational context, Brass et al. (2004) concluded that actor similarity is an antecedent for interpersonal network formation. In other words, similarity can breed informal business-related connections among firms over and above formal structures (Makela et al., 2007). As a result, because it is difficult to transfer complex technologies (Kogut \& Zander, 1993), such process requires frequent interaction (Hansen et al., 2005) among firms with similar characteristic of firms.

Hypothesis 2: The similarity of firms within network is positively related to technology transfer through international network structure.

\section{National Culture in the International Network}

Recently, the issue of cultural context emerges again from the network theory. Xiao and Tsui (2007) insisted that the control and information benefits of central actor (structural holes) in the network structure cannot materialize, due to cultural variance in some organizations. Also, they argued that an important insight of social network perspective is that actions and outcomes can be predictive by the relational character and the national culture is contingent factor affecting outcomes from network, such as network effectiveness and learning (Provan, Fish, \& Sydow, 2007). In the international business network, however, the national culture is a type of "conduit" or "tie" rather than contingent factor, because cultural variations across nations among firms that are involved in the international business network can directly affect the outcomes from the success of business work (Kedia \& Bhagat, 1988).

Inside the network perspective, the conduit or tie of the firms is difficult to imitate and has distinctive characteristics, which are the information sharing (Sharma \& Blomstermo, 2003), and referral (Burt, 1992) etc.. Firstly, the technology would be transferred through the same national culture as firms' ties. A tie facilitates technology or knowledge transfer by firm's decision making process (Palmer, Friedland, \& Singh, 1986). The cultural bond of each firm's managers or board members context may be considered in the firm's decision, making process for technology transfer because of reducing transfer cost from different social contexts, for example, reciprocity has long been recognized as the principle in exchange networks (Gouldner, 1960). It has, however, greater importance in Asian countries where there is a stronger emphasis on trusting and mutual obligation than western countries (Lincoln, Gerlach, \& Takahashi, 1992). Secondly, referrals imply the right time and the right place of firm's interests (Sharma \& Blomstermo, 2003). Center firms in a network may receive more technology compared to their competitors (Burt, 1992). However, the advantage of brokering position in the network cannot be realized by culture (Xiao \& Tsui, 2007). It means that an apparent tie of firms would be affected by another type of ties such as "guanxi" in China. The present study demonstrates that 
various types of interorganizational ties have different effects on network outcomes (Gulati \& Higgins, 2003). Accordingly, from the finding of Xiao and Tsui (2007), the national culture is a type of ties affecting the network outcomes in the international business.

Meanwhile, one of the most important characteristics of network structure is the density of ties. Density describes the overall level of interaction of various kinds reported by network member (Sparrowe, Liden, Wayne, \& Kraimer, 2001). The density of ties in a network tends to increase or decrease over time (Venkatraman \& Lee, 2004), because time may modify the flow through the change of network features and the form of network structure (Soda, Usai, \& Zaheer, 2004). The cultural context is also influenced by time just like the dimension of the network. Needless to say, the national culture changes slowly but absolutely. Although cultural boundaries among nations gradually become ambiguous with increasing economic integration (Fukuyama, 1995), the unique national culture encompasses every aspect of a firm's activity, for example, because the national culture or corporate culture can dissuade actors from exercising the maximum degree of opportunism (Koford \& Miller, 2006), the culture is one of the most important criteria of partner selection of the international alliance (Dong \& Glaister, 2006). Then, the national culture may play a role of tie on the international business network.

The other characteristic of the national culture as international network tie is embeddedness. The relational embeddedness describes the kind of personal relationships. Actors have developed with each other through a history of interaction (Granovetter, 1992) and have focused on the particular relations that influence actor's behavior (Nahapiet \& Ghoshal, 1998). Also, the concept of embeddedness has been adapted for a number of different dimensions. One of the adaptations is the cultural embeddedness (James, 2007). The cultural embeddedness is treated only as the effects of national cultures with current conceptions of culture as rules and practices (Whittington, 1992). The national culture provides the categories and understandings that enable actors to engage in economic and social action, and culture provides shared norms that constrain action (DiMaggio, 1994). Accordingly, the national culture is not only shared values that reinforce the belief, intention, and collective activity but also as complex rule-like structures that constitute resources to realize strategic purpose (DiMaggio, 1997). In this regard, the national culture is one of the essential eliments affecting the formation, maintenance, and outcomes of international business network, and the technology transfer occurs in a shared culture in which different units are linked to one another (Tsai, 2001). As a result, the national culture has the features of both the node and conduit or tie of firms within same culture.

Hypothesis 3: The distance of national culture within network is negatively related to technology transfer through international network structure.

\section{Analyses and Methods}

This study was conducted by research analysis in the aerospace industry. The aerospace industry is not only a high technology-based industry (Jorge \& Jhegu, 2005), but it also is an industry where the firms cannot ensure successful survival without technology transfer (Stuart, 2000). Accordingly, the technology transfer is extremely critical issue in the aerospace industry, compared to other industries.

Secondary data from the securities data company (SDC) database in Thomson financial is used for this study. The sample size is 125 cases from January 1980 to December 2000. All cases involved international R\&D consortium in the aerospace industry, classified at the international alliance category of Thomson financial criteria. Given the data structure, the study employed binomial logistic regression analysis to test the 
relationship between the various independent variables and technology transfer.

To compute network measure, matrices of the relationships among the firms representing "strength of tie" were constructed. The matrices were input into UCINET VI, a software package that allows the computation of network measures (Borgatti, Everett, \& Freeman, 1992). The multidimensional scaling was used and it referred to a set of methods used to obtain inside representations of the cultural proximity (national culture) among firms in the international R\&D network. The network in this research was cumulative and encompassed all international R\&D consortiums that have been formed between 1980 and 2000.

\section{Definition and Measurement of Variables}

The dependent variable, "technology transfer", was coded as " 1 ", if the technology is transferred among firms through R\&D consortium and as " 0 " if otherwise. Although the item of technology transfer is indicated as either "yes" or "no" in the SDC database, direct coding was used to identify all deals made via R\&D consortiums, for example, the following illustrates two brief deals in text regarding technology transfer (Tsai, 2005; Simonin, 2004): ... A company agreed to share data, computer programs, and design methods..., or ... B company received technical support from $\mathrm{C}$ company...

The strength of dyadic tie. A multiplex tie or multiplexity is assumed to be an indicator of the strength and durability of an organization's links, because it enables an organization and its partner to maintain a relationship, even if one type of link dissolves (Provan et al., 2007). In this research, the multiplexity is measured as the sum of closeness centrality score and experience of R\&D consortium for each firm across all its partners (Hansen, 1999). Closeness centrality captures how closely a firm is connected to the rest of the firms in the interfirm network (Gulati, 1998). It is computed by counting the number of firms that a focal firm must go through to reach other firms in the network (Freeman, 1979). Experience captures the number of R\&D consortiums a firm has formed. All the prior $R \& D$ consortiums a firm has entered with any partner is counted. The multiplex tie of the focal firm is then revealed by the score of the sum of two variables, because the ties are based on the number of types of link (Provan et al., 2007).

Firm's similarity. Firm similarity is defined by the industries of the participants of R\&D consortium (Morosini, Shane, \& Singh, 1998), and a recent research has found SIC-based (Standard Industrial Classification) measures of business similarity to be closely associated with them (Flanagan, 1996). All four-digit SIC codes among participants in the aerospace industry were classified into six categories by the criteria found in the World Wide business directory. Firm similarity is identified as the deal where the participants operate in the same three-digit SIC code.

Cultural distance. Leading research about dimensions of national culture was achieved by Hofstede (1980). In his pioneer work, although national cultures are different in every country, the similarities and differences of some national culture were indicated. Following his research, Kogut and Singh (1988) developed that a cultural distance is an important factor affecting the success on the international business. Also, cultural differences between the knowledge transferor and the transferee act as one of organizational communication barriers (Lin \& Berg, 2001). In this research, cultural distance is defined measurement by Morosini et al. (1998).

Based on prior research, two control variables are distinguished for model. First, firm's size is operationalized as the number of employee (Prater \& Ghosh, 2006) to capture any effect of firm's size on alliance activity (Gulati, 1998). National relationship is also included and measured by national agreement in 
the aerospace industry — as the second control variable, because, according to Lawrence (1998), breaking the link between aerospace industry and the state is unlikely to happen. Currently, there exist two global agreements in the aerospace industry: GATT (General Agreement on Trade and Tariffs) and ESA (European Space Agency). ${ }^{11}$ The variable was coded as " 1 " if parent nation of firm is part of the GATT or ESA, and "0" if otherwise.

\section{Results}

Prior to the assessment of the hypotheses of this study, a correlation analysis of the variables is performed. Table 1 shows the mean values, standard deviations, and correlations for all the measured variables. The all correlation coefficients show the threshold of 0.7 below which is used as a rule of thumb for collinear relationship and multicollinearity (Anderson, Sweeney, \& Williams, 1996), and the results of the regression model show no sign of the bias.

Table 1

Means, Standard Deviations, and Correlation

\begin{tabular}{lllllllll}
\hline & Mean & s.d. & 1 & 2 & 3 & 4 & 5 & 6 \\
\hline 1. Firm's size & 127,631 & 100,249 & 1 & & & & & \\
2. National relation & 0.63 & 0.48 & $-0.273^{* *}$ & 1 & & & & \\
3. Strength of tie & 4.16 & 6.11 & $-0.372^{* *}$ & $0.239^{* *}$ & 1 & & & \\
4. Similarity & 0.36 & 0.48 & $0.199^{*}$ & 0.158 & 0.149 & 1 & & \\
5. Cultural distance & 30.25 & 26.33 & -0.158 & $-0.382^{* *}$ & -0.221 & -0.061 & 1 & \\
6. Technology transfer & 0.60 & 0.49 & -0.031 & $0.223^{*}$ & $0.240^{* *}$ & $0.204^{*}$ & $-0.251^{* *}$ & 1 \\
\hline
\end{tabular}

Notes. * Correlation is significant at the 0.05 level (2-tailed); ** correlation is significant at the 0.01 level (2-tailed).

Figure 1 demonstrates the pattern of cultural similarities among the firms which join in the international R\&D network. The goodness of fit in this two dimensional model is excellent (stress value -0.0001). According to the Figure 1, there are two different ties in the aerospace industry. One is the tie of national culture by dimension 2 and the other is the strength of ties by dimension 1. U.S. firms, such as Boieng, General Dynamics, and etc., are located to center of international R\&D network from dimension 1 , and they can play the role as broker with transferring technology in the international R\&D network. Future studies should examine the difference between dimension 1 and apparent network structure.

The result of the logistic regression analysis supports the hypotheses. The result of the model is presented in Table 2. Firstly, firm's size and national relationship were shown as not significant. Although the national relationship is an important factor, especially, in the aerospace industry, technology cannot transfer through the national relationship.

Hypothesis 1 states that the strength of dyadic ties is positively related to technology transfer. As shown in Table 2, the logistic coefficient is positive and significant $(p<0.05)$, which indicates that the strength of ties among firms in the aerospace industry contributes to the transfer of technology. Hence, hypothesis 1 is supported.

Hypothesis 2 assumes a positive correlation between firm similarity as the characteristic of nodes and

\footnotetext{
${ }^{1}$ GATT (General Agreement on Trade and Tariffs) includes the following countries: Austria, Belgium, Canada, Denmark, EEC, Germany, France, Ireland, Italy, Japan, Luxembourg, Netherlands, Norway, Romania, Sweden, Switzerland, U.K., and U.S.; ESA (European Space Agency) includes the following countries: Austria, Belgium, Denmark, Finland, Germany, France, Ireland, Italy, Netherlands, Norway, Sweden, Switzerland, U.K., Portugal, and Spain.
} 
transfer technology. The logistic coefficient of firm similarity is positive and weakly significant $(p<0.1)$, which indicates that firm similarity as the characteristic of nodes in the international network may be related to transfer technology. As a result, hypothesis 2 is also supported. Consistent with previous research, this implies that strong ties and similarity of actors can effectively improve the network outcomes such as technology transfer.

Hypothesis 3 states that the distance of national culture is negatively related to technology transfer. The logistic coefficient of cultural distance is negative and significant $(p<0.01)$, and the national culture would strongly play the role of conduit or tie among firms to achieve network outcomes, such as technology transfer and network effectiveness in the international network.

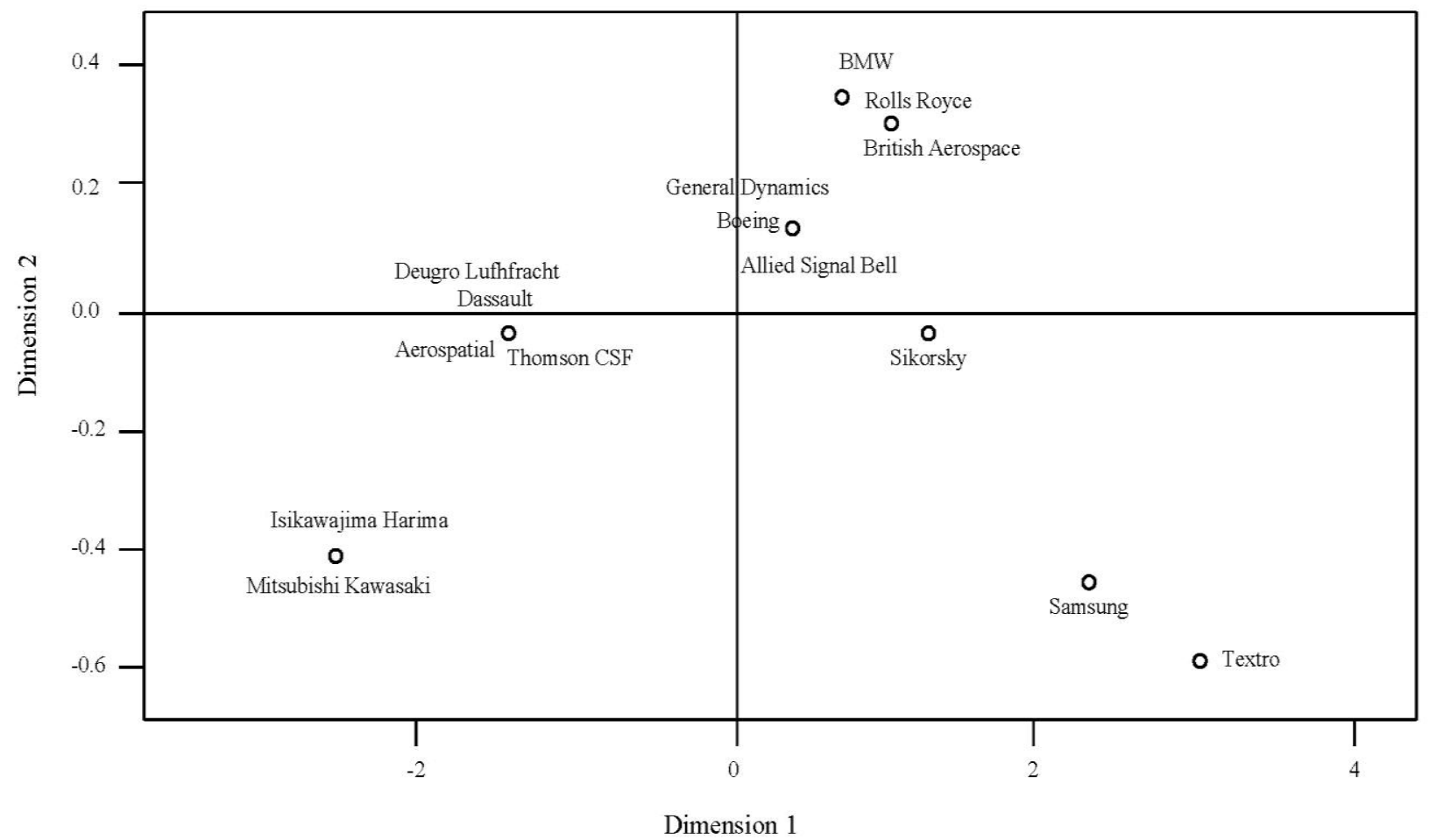

Figure 1. The pattern of cultural similarities in the international R\&D network.

Table 2

Regression Results for Technology Transfer Through International Network

\begin{tabular}{llll}
\hline & & \multicolumn{2}{c}{ Technology transfer through R\&D consortium } \\
\cline { 3 - 4 } & & Model 1 & Model 2 \\
\hline Control & Firm's size & $-0.015(0.876)$ & $-0.148(0.186)$ \\
& National relation & $0.724(0.100)^{*}$ & $0.128(0.800)$ \\
Independent variables & Strength of tie & & $0.096(0.025)^{* *}$ \\
& Firm Similarity & & $0.832(0.083)^{\dagger}$ \\
Constant & Cultural distance & & $-0.023(0.017)^{* *}$ \\
Chi-Square & & $0.100(0.814)$ & $0.943(0.129)$ \\
$N$ & & $2.660(0.264)$ & $16.868(0.005)^{* *}$ \\
Correct Classification $(\%)$ & 125 & 125 \\
\hline
\end{tabular}

Notes. ** 0.01 level; *0.05 level; $\uparrow 0.1$ level (2-tailed). 


\section{Conclusions}

How can a firm in the international business network acquire useful technology from other firms to make new or better products? This study suggests that strong ties, firm similarity, and national culture are critical factors in answering this question. Technology is a major source of competitive advantage and a critical strategic asset in the aerospace industry (Stuart, 2000). However, because successful technology transfer is difficult in international network and high technology-based industry, transfer mechanism is required for smooth transactions (Sunaoshi et al., 2005). Consequently, this study analyzed various factors affecting technology transfer via international business network.

The result suggests that the strength of ties is positively associated with greater chance of successful technology transfer. Several studies have shown that technology transfer is facilitated by the extent to which two parties strongly establish their relations (Hansen, 1999; Szulanski, 1996). The hypotheses in this research support the positive relationship between the strength of tie and transfer. This result is significant, because it addresses some critical problems in international R\&D strategy. Internationalization of R\&D is achieved by creating technologies via access to overseas technology (Belderbos, 2002), however, merely participating in R\&D consortium cannot ensure technology transfer. It is interesting to observe that successful technology transfer takes place through strong tie among firms with repeated R\&D consortium. In 2002, Sakakibara (2002) called attention to the network effect on R\&D consortia, though it received limited attention in managerial literature. In this light, adopting a relational approach to study transfer technology in R\&D consortium can be a basis for further research.

This study also notes the significance in the relation between firm similarity and technology transfer. Monteiro, Arvidsson, and Birkinshaw (2004) purported that firms have the tendency to communicate more intensively with similar others, leading to uneven patterns of technology flows. In this regard, Von Hippel (1994) has presented the concept of "stickiness" of knowledge to refer to the additional costs to transfer technology from one practice to another (Szulanski, 2003). Therefore, stickiness of knowledge becomes an obstacle in technology transfer (Von Hippel, 1994). The transfer costs will increase, when the technology provider and the recipient operate in different contexts are engaged in different practices. However, when the technology provider and the recipient share the same context and are engaged in the same practice, the costs of stickiness will be relatively reduced (Van Baalen, Bloemhof-Ruwaard, \& Van Heck, 2005). Accordingly, the further studies with network theory should never overlook at the characteristics of nods or actors itself.

Finally, the national culture is a conduit and tie of international firms. The firms which reside in the same regional sector, such as Asia, North America, Europe, and etc. have cultural capital, like social capital, compared to other firms in the different regional sector. Moreover, cultural capital is seen as a resource that inheres in a focal firms' international network to give the firm some advantages in competitive rivalries. Compared to social capital, cultural capital may be the most important variable in the research of international business network. Furthermore, despite the lack of recent attention in the international business field, the national culture deserves a better treatment as an important issue in the field. The focus of study was on the transfer of technology via international network. Based on the findings, the structure of international business network would be built with superficial or external ties and fundamental or internal ties. Then, both ties in the international business network can play a significant role in achieving the network outcomes. 
Although this research focuses on the technology transfer through international network, it is necessary to study the unique international network structure itself. Also, other types of national connections, such as political and military connection, may affect the firm's network outcomes. Further study pursuing this line of questions has great potential to make significant contributions to the research of the international business network.

\section{References}

Albors, J., Sweeney, E., \& Hidalgo, A. (2005). Transnational technology transfer networks for SMEs. A review of the state-of-the art and an analysis of the European IRC network. Production Planning \& Control, 16(4), 413-423.

Amesse, F., \& Cohendet, P. (2001). Technology transfer revisited from the perspective of the knowledge-based economy. Research Policy, 30, 1459-1478.

Anderson, D. R., Sweeney, D. J., \& Williams, T. A. (1996). Statistics for business and economics. St Paul: West Publishing Company.

Belderbos, R. (2002). Entry mode, organizational learning, and R\&D in foreign affiliates: Evidence from Japanese firms. Strategic Management Journal, 24, 235-259.

Borgatti, S. P., Everett, M. G., \& Freeman, L. C. (1992). UCINET IV. Columbia: Analitic technologies.

Brass, D. J., Galaskiewicz, J., Greve, H. R., \& Tsai, W. (2004). Taking stock of networks and organizations: A multilevel perspective. Academy of Management Journal, 47(6), 795-817.

Burt, R. S. (1992). Structural holes: The social structure of competition. Cambridge: Harvard University Press.

Carley, K. (1991). A theory of group stability. American Sociological Review, 56, 331-354.

Daghfous, A. (2004). An empirical investigation of the roles of prior knowledge and learning activities in technology transfer. Technovation, 24(12), 939-953.

DiMaggio, P. J. (1994). Culture and economy. In N. J. Smelser, \& R. Swedberg (Eds.), Handbook of economic sociology. Princeton: Princeton University Press

DiMaggio, P. J. (1997). Culture and cognition. Annual Review of Sociology, 23, 263-289.

Dong, L., \& Glaister, K. W. (2006). Motive and partner selection criteria in the international strategic alliances: Perspectives of Chinese firms. International Business Review, 15(6), 577-600.

Duysters, G., De Man, A., \& Wildeman, L. (1999). A network approach to alliance management. European Management Journal, 17(2), 182-187.

Flanagan, D. (1996). Announcements of purely related and purely unrelated mergers and shareholder returns: Reconciling the relatedness paradox. Journal of Management, 22(6), 823-835.

Freeman, L. C. (1979). Centrality in social network: conceptual clarification. Social Network, 1, 215-239.

Fukuyama, F. (1995). Trust: The social virtues and the creation of prosperity. New York: Free Press.

Gilbert, M., \& Cordey-Hayes, M. (1996). Understanding the process of knowledge transfer to achieve successful technological innovation. Technovation, 16, 301-312.

Gouldner, A. W. (1960). The norm of reciprocity: A preliminary statement. American Sociological Review, 25, 161-178.

Granovetter, M. (1973). The strength of weak ties. American Journal of Sociology, 78, 1360-1380.

Granovetter, M. (1992). Problems of explanation in economic sociology, networks and organizations: Structure, form and action. Boston: Harvard Business School Press.

Gulati, R. (1998). Alliance and networks. Strategic Management Journal, 19(4), 293-317.

Gulati, R., \& Higgins, M. C. (2003). Which ties matter when? The contingent effects of interorganizational partnerships on IPO success. Strategic Management Journal, 24, 127-144.

Hagedoorn, J. (1993). Understanding the rationale of strategic alliance partnering: Inter-organizational mode of cooperation and sectoral differences. Strategic Management Journal, 14(5), 371-378.

Hansen, M. T. (1999). The search-transfer problem: The role of weak ties in sharing knowledge across organization subunits. Administrative Science Quarterly, 44, 82-111.

Hansen, M. T., Mors, M. L., \& Lovas, B. (2005). Knowledge sharing in organizations: Multiple network, multiple phases. Academy of Management Journal, 48(5), 776-793.

Hemmert, M. (2004). The impact of internationalization on the technology sourcing performance of high-tech business units. Journal of Engineering and Technology Management, 21(3), 149-174. 
Henderson, R. M., \& Clark, K. B. (1990). Architectural innovation: The reconfiguration of existing product technologies and the failure of established firms. Administrative Science Quarterly, 35(1), 9-30.

Henderson, R., \& Cockburn, L. (1994). Measuring competence? Exploring firm effects in pharmaceutical research. Strategic Management Journal, 15, 63-84.

Hofstede, G. (1980). Culture's consequences: International differences in work-related values. London: Sage Publications.

James, A. (2007). Everyday effects, practices and causal mechanism of cultural embeddedness: Learning from high tech regional economy. Geoforum, 38(2), 393-413.

Johanson, J., \& Mattson, L. G. (1987). International relations in industrial system: A network approach compared with the transaction-cost approach. International Studies of Management and Organization, 18(1), 34-48.

Jorge, N., \& Jhegu, M. (2005). Globalization and the patterns of Industry location: The case of the aerospace industry. Proceedings from Innovation Systems Research Network, 7th Annual Meeting.

Kedia, B. L., \& Bhagat, R. S. (1988). Cultural constraints on transfer of technology across nations: Implications for research in international and comparative management. Academy of Management Review, 13(4), 559-571.

Koford, K., \& Miller, J. B. (2006). Contract enforcement in the early transition of an unstable economy. Economic System, 30(1), $1-23$.

Kogut, B., \& Singh, H. (1988). The effect of national culture on the choice of entry mode. Journal of International Business Studies, 19(3), 411-432.

Kogut, B., \& Zander, U. (1992). Knowledge of the firm, combinative capabilities, and the replication of technology. Organization Science, 3, 383-397.

Kotabe, M., Dunlap-Hinkler, D., Parente, R., \& Mishra, H. A. (2007). Determinants of cross-national knowledge transfer and its effect on firm innovation. Journal of International Business Studies, 38, 259-282.

Lawrence, P. (1998). Strategic issues in the European aerospace industry. Aldershot: Ashgate Publishing.

Lin, B. W., \& Berg, D. (2001). Effects of cultural difference on technology transfer projects: An empirical study of Taiwanese manufacturing companies. International Journal of Project Management, 19(5), 287-293.

Lin, N., Ensel, W. M., \& Vaughn, J. C. (1981). Social resources and strength of ties: Structural factors in occupational status attainment. American Sociological Review, 46, 393-405.

Lincoln, J. R., Gerlach, M. L., \& Takahashi, P. (1992). Keiretsu networks in the Japanese economy: A dyad analysis of intercorporate ties. American Sociological Review, 57, 561-585.

Link, A., \& Bauer, L. (1989). Cooperative research in US manufacturing: Assessing polish initiatives and cooperative strategy. Toronto: Lexington Books.

Makela, K., Kalla, H. K., \& Piekkari, R. (2007). Interpersonal similarity as a driver of knowledge sharing within multinational corporations. International Business Review, 16, 1-22.

McPherson, J. M., Smith-Lovin, L., \& Cook, J. M. (2001). Birds of a feather: Homophily in social networks. Annual Review of Sociology, 27, 415-444.

Medcop, J. W. (2001). Resource-based strategy and managerial power in networks of internationally dispersed technology units. Strategic Management Journal, 22, 999-1012.

Mehra, A., Kildduff, M., \& Brass, D. J. (1998). At the margins: A distinctiveness approach to the social identity and social networks of underrepresented group. Academy of Management Journal, 41, 441-452.

Monge, P. R., \& Contractor, N. S. (2003). Theories of communication networks. New York: Oxford University Press.

Monteiro, F., Arvidsson, N., \& Birkinshaw, J. (2004). Knowledge flows within multinational corporations: Why are some subsidiaries isolated? Academy of management best conference paper series, p. B1.

Morosini, P., Shane, S., \& Singh, H. (1998). National cultural distance and cross-border acquisition performance. Journal of International Business Studies, 29(1), 137-158.

Nahapiet, J., \& Ghoshal, S. (1998). Social capital, intellectual capital, and the organizational advantage. Academy of Management Review, 23(2), 242-266.

Orru, M. (1991). Practical and theoretical aspect of Japanese business networks. Organization Studies, 10, 549-574.

Palmer, D., Friedland, R., \& Singh, J. V. (1986). The ties bind: Organizational and class bases of stability in a corporate interlock network. American Sociological Review, 51, 781-796.

Parkhe, A. (1991). Interfirm diversity, organizational learning, and longevity. Journal of International Business Studies, 22(4), 579-601.

Patibandla, M., \& Petersen, B. (2002). Role of the transnational corporations in the evolution of a high-tech industry: The case of India's software industry. World Development, 30(9), 1561-1577. 
Pennings, J. H., \& Harianto, F. (1992). Technology networking and innovation implementation. Organization Science, 3, 356-382.

Powell, W. (1990). Neither market nor hierarchy: Network forms of organization. Research in Organizational Behavior, 12, 295-336.

Prater, E., \& Ghosh, S. (2006). A comparative model of firm size and the global operational dynamics of U.S. firms in Europe. Journal of Operations Management, 24(5), 511-529.

Provan, K. G., Fish, A., \& Sydow, J. (2007). Interorganizational network at the network level: A review of the empirical literature on whole networks. Journal of Management, 33, 479-516.

Sakakibara, M. (2002). Formation of R\&D consortia: Industry and company effect. Strategic Management Journal, 23, 1033-1050.

Sapienza, H. J., Parhankangas, A., \& Autio, E. (2004). Knowledge relatedness and post spin off growth. Journal of Business Venturing, 19, 809-829.

Sharma, D. D., \& Blomstermo, A. (2003). The internationalization process of born globals: A network view. International Business Review, 12(6), 739-753.

Simonin, B. L. (2004). An empirical investigation of the process of knowledge transfer in international strategic alliances. Journal of International Business Studies, 35, 407- 427.

Sirmon, D. G., \& Lane, P. J. (2004). A model of cultural differences and international alliance performance. Journal of International Business Studies, 35, 306-319.

Soda, G., Usai, A., \& Zaheer, A. (2004). Network memory: The influence of past and current networks on performance. Academy of Management Journal, 47(6), 893-906.

Sparrowe, P. T., Liden, R. C., Wayne, J., \& Kraimer, M. L. (2001). Social networks and the performance of individuals and groups. Academy of Management Journal, 44(2), 316-325.

Stuart, T. E. (2000). Inter-organizational alliance and performance of firm: A study of growth and innovation rates in high technology industry. Strategic Management Journal, 21, 791-811.

Sunaoshi, Y., Kotabe, M., \& Murray, J. Y. (2005). How technology transfer really occurs on the factory floor: A case of a major Japanese autonomotive die manufacturer in the U.S.. Journal of World Business, 40, 57-70.

Szulanski, G. (1996). Exploring internal stickiness: Impediments to the transfer of best practice within the firm. Strategic Management Journal, 17, 27-43.

Szulanski, G. (2003). Sticky knowledge. Barriers to knowing in the Firm. London: Sage Publications.

Tsai, M. T. (2005). An empirical study of the knowledge transfer methods used by clinical instructors. International Journal of Management, 22(2), 273-284.

Tsai, W. (2001). Knowledge transfer in interorganizational networks: Effects of network position and absorptive capacity on business unit innovation and performance. Academy of Management Journal, 44(5), 996-1004.

Tsai, W., \& Ghoshal, S. (1998). Social capital and value creation: The role of interfirm network. Academy of Management Journal, 41(4), 464-476.

Van Baalen, P., Bloemhof-Ruwaard, J., \& Van Heck, E. (2005). Knowledge sharing in an emerging network of practice: The role of a knowledge portal. European Management Journal, 23(3), 300-314.

Venkatraman, N., \& Lee, C. (2004). Preferential linkage and network evolution: A conceptual model and empirical test in the U.S. video game sector. Academy of Management Journal, 47(6), 876-888.

Von Hippel, E. (1994). Sticky information and the locus of problem solving: Implications for innovation. Management Science, 40(4), 429-439.

Weimann, G. (1982). On the importance of marginality: One more step into the two-step flow of communication. American Sociological Review, 47(6), 764-773.

Whittington, R. (1992). Putting giddens into action: Social systems and managerial agency. Journal of Management Studies, 29(6), 693-712.

Xiao, Z., \& Tsui, A. S. (2007). When brokers may not work: The cultural contingency of social capital in Chinese high-tech firms. Administrative Science Quarterly, 52, 1-31. 